\title{
Financial Engineering, Corporate Goverance and Nigeria Economic Development
}

\author{
John Ifeanyichukwu Osuoha \\ Department of Accounting and Finance, Faculty of Business and Law, Leeds Metropolitan University, \\ Leeds, UK \\ Email: johngiftconsulting@yahoo.com
}

Received July 23 ${ }^{\text {rd }}$, 2013; revised August 23 ${ }^{\text {rd }}$, 2013; accepted September $1^{\text {st }}, 2013$

Copyright (C) 2013 John Ifeanyichukwu Osuoha. This is an open access article distributed under the Creative Commons Attribution License, which permits unrestricted use, distribution, and reproduction in any medium, provided the original work is properly cited.

\begin{abstract}
The study shows that the present Nigeria financial system is incomplete and lacking in hedging mechanism. The Nigeria financial system has only organized Money Market and Capital Market. Although these markets have proved useful in mobilizing resources for firms and governments for development and growth of the economy but they are very vulnerable and not fully developed as expected because of the absence of an organized derivatives market. Derivatives markets suppose to provide an impetus and encouragement for more investors (both local and foreign) to patronize the money and capital markets knowing the risk of their investments can be managed. Also Nigeria abundant oil and gas resources are lacking in hedging mechanism to manage the volatility of oil and gas prices in the international market which directly affect the wealth and economic development of Nigeria. Therefore, Nigeria government and corporate leaders should fast tract the establishment of derivatives exchange in Nigeria where futures and options on Nigeria Mineral resources, agricultural produce and other basic instruments can be traded. This will attract more foreign investments in the Nigeria financial markets thus boosting liquidity of the market, increasing market depth and enhancing economic growth.
\end{abstract}

Keywords: Financial Engineering; Derivatives; Corporate Governance; Regulation; Economic Development

\section{Introduction}

Financial engineering is the use of financial Instruments to restructure an existing financial profile into one having more desirable properties (Galits, 1995). Financial engineering combines a rigorous study of computative mathematics with economics and quantitative finance. Financial engineers are the specialists who deal with the quantitative aspect of the derivatives market. Financial engineering is a useful tool for economic planning and in effect a tool for economic transformation. Financial engineering is usually employed in valuation of securities, and management of risks, financial management, Insurance, taxation, derivative accounting, commodity trading and other financial decision applications. Financial engineering can be applied by individual firms in an economy. It can also be used by local, state and federal Governments in their economic planning, foreign reserve management, and commodity export risk management and a number of other applications. Financial engineering combines or carves up existing financial assets to create new financial products (Harvey, 2005).

Financial engineering is also intended to split risk and return components of financial products/instruments and offering the combination which is best suited to Investor's risk-return profile (Shah \& Serinivasan, 2010). Financial engineering may provide the expertise to handle the regulatory reforms during the financial crises of 2007/2008 (Lo, 2009). According to Cole et al. (2009), financial engineering provides potential in reducing consumption fluctuations and lower adoption of risk man- agement technology during selected seasons.

Shah and Serimivasan (2010) views financial engineering as an engineering discipline which deals with the creation of new and improved financial products through innovative design or repackaging of existing financial instruments. They consider financial engineering as pervasive spanning across design of innovative financial instruments, financing merger and acquisition deals, corporate restructuring, derivative trading strategies to mention but a few. Financial engineering and its innovative products have played an important role in expanding sources of finance and meeting Investors and Issuers requirements. However, the field of financial engineering needs much more development to ensure wider choice of investment products for investors and wider choice of financing for firms and governments. Financial engineering and derivatives usage produce efficiency in capital market, stock market and other basic market. Arguably, the single largest innovation in global financial markets over the past two decades has been the emergence and growth of derivative market (Gupta, 2004). Financial Engineers are responsible for combining, designing, researching, developing and implementing a range of innovative financial instruments for commercial use. The work of financial engineers covers a wide variety of sophisticated financial instruments (Abumustafa \& Al-Abduljader, 2011). In a study, "Modeling Financial Innovation and Economic Growth: Why the financial sector matters to the Real Economy”, Chou (2007), extending the classic Solow (1956) model finds that financial innovation 
raises the efficiency of financial intermediation by increasing the variety of financial products and services. The resulting capital accumulation leads to economic growth. Financial engineering and innovations may be motivated by a need to hedge some economic risk. Financial innovations may involve inventing brand new classes of products, modifying existing products; or combining the characteristics of several existing products (Chou, 2007). Perez (2002) explains that financial engineering/innovations have been associated with each technological revolution. Financial engineering products such as derivatives can be simple and straightforward which are refereed as plain vanilla and can also be complicated and exotic As at shown in Figure 1.

The rest of this paper is divided into the following sections:

1) The relationship between financial engineering, economic development and growth;

2) The role of Corporate governance in Financial engineering and derivatives market development;

3) Responsibility of the Board, Board Structure and Derivatives use;

4) Regulation of Financial engineering and derivatives market;

5) Recommendations;

6) Conclusion.

\section{Relationship between Financial Engineering, Economic Development and Growth}

The study of finance and development can be traced back to Schumpeter (1911). There have been extensive empirical evidences supporting the assertion and belief that financial developments lead to economic growth, Levine and Zervos (1998). Financial engineering products and derivatives are product of financial development. Factors underlying financial development have been identified by Andrianaivo and Yartey (2010). In their study, using a panel of 53 countries for the period 1990-2006, they examined the impact of income level, macroeconomic stability, financial liberalization and institutional quality on both banking sector and the stock market development. They found empirically the determinants of financial market development in Africa with an emphasis on the banking system and stock market. According to Andrianaivo and Yartey (2010) Income level, creditor rights protection, financial repression and political risk are the main determinants of banking sector development in Africa, stock market liquidity, domestic savings, banking sector development and political risk are the main determinants of stock market development. However, financial market cannot be complete without derivatives market. The banking/money market and the stock market all depend on the derivatives market to manage the risk inherent in their operations. One key role of derivatives is to complete the financial market and to provide avenue for managing the risks associated with the use of other markets such as banking, stock market, commodity market, energy market, power market to mention but a few. Economic development of Nigeria is dependent on stock market development (SMD), Money Market Development (MMD), Derivatives market Development (DMD) and other Factors (OFS) as shown in Figure 2. Other factors will usually include government policies and regulatory environment, social-political environment, Gross Domestic product, Agriculture, Energy, Power, other infrastructures and other economic development drivers.

Neglecting the Derivatives market Development will break the chain of development and stall economic growth. The MMD,

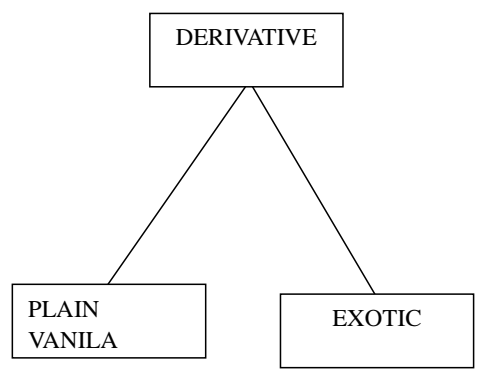

Figure 1.

Derivatives classification. Source: Author.

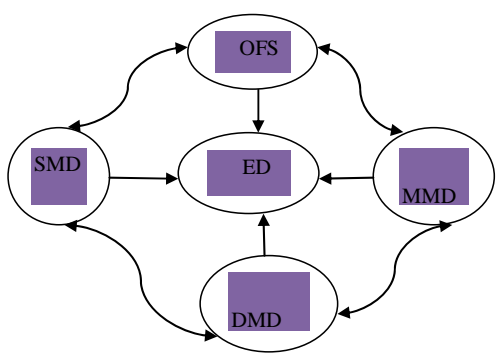

Figure 2.

Economic development drivers. ED: Economic Development; MMD: Money Market Development; SMD: Stock Market Development; DMD: Derivatives Market Development; OFS: Other Factors; Source: Author.

SMD and OFS can all be improved by structuring derivatives on them to manage them. For example, equity call and put options can improve the performance of the stock market. Interest rate futures can enhance the value and performance of the money market. Forward and futures contract on maize, cocoa and other agricultural produce can help stabilize the price of the agricultural market and provide food at affordable prices. Energy options can be used to manage the risk inherent in the Oil and Gas market. Futures, options and other derivatives can still be structured on power, transportation/freight, weather condition etc. Every propeller of economic development can be managed and enhanced with the use of derivatives products.

Earlier, Dermirguc-kunt and Levine (1996) have found that most stock market indicators are highly correlated with banking sector development. Countries with well developed banking sector also tend to have well developed stock markets. Levine and Zervos (1998), show that stock market development affects growth through capital accumulation and improvement in productivity. On the relationship between stock market growth and economic growth, El-Wassal (2005) found that economic growth, financial liberalization and foreign portfolio investments were the leading factors in emerging market between 1980 and 2000. Cecchetti and Kharroubi (2012) have a different view on the relationship between financial development and growth. They reassessed the impact of finance and growth. Their finding shows that the level of financial development is good only up to a level or point, after this point, it becomes a drag on growth. The samples used were data from both developed and developing economies. When focused on advanced economies, they show that a fast-growing financial sector is detrimental to aggregate productivity growth. Financial sector size has an inverted U-shaped effect on productivity growth. 
There comes a point where further enlargement of the financial system can reduce real growth. Financial sector growth is found to be a drag on productivity growth. The authors believe that the reason for this is that financial sector competes with the rest of the economy for scarce resources so that financial booms are not, in general growth-enhancing.

However, while this may be true for already developed economies with well developed financial market, it cannot be said of Nigeria and other developing economies. Financial development should be growth-enhancing for Nigeria. The growth and consolidation of Nigeria banks and the stock market has provided both short term and long term finance to support industries, firms, governments, infrastructures development and business initiatives which in turn produce growth. The development of derivatives market should have positive impact on economic development of Nigeria. Derivatives market should bring about increased liquidity, increased capital flow, increased market depth, increased confidence in the basic markets, predictable cash flows from oil, protection of foreign reserves, enhanced price discovery to mention but a few.

\section{Role of Corporate Governance in Financial Engineering and Derivatives Market Development}

Strong, effective corporate governance is essential to the functioning of derivatives market (ISDA, 2002). What is corporate governance? The definition of corporate governance depends on one's view of the world (Gillan, 2006). The model of corporate governance has been differently defined and the best way to look at the concept is to list a few of the different definitions instead of mentioning one (Maw \& Cring-Cooper 1994). These definitions vary across countries/region being contingent on different legal, political, economic, cultural, religious and ethical underpinning.

Before examining some of the several definitions, let's consider the origin of the word "governance". According to Tricker (1984), the origin of the word governance can be found in the Latin word "gubernare" meaning "to rule" or "to steer" and the greek word, "kybernetikos" which means steering. Nobert Wiener used the Greek root as the basis for cybernetics. Cybernetics is the science of control in man and machine. The idea of the steer man is a particularly helpful insight into the reality of governance. Also Rwegasira (2000) opined that governance in a cybernetic concept, referring cybernetics specifically to the feedback and control mechanism by which a system, and any system for that matter, keeps itself oriented towards the goals for which it was created. Let's now examine some definitions of corporate governance.

Demb and Neubauer (1992) defined Corporate governance as the process by which Corporations are made responsive to the rights and wishes of shareholders. To Cadbury (1992), "Corporate governance is the system by which companies are directed and controlled". According to Blair (1995) Corporate governance is about "the whole set of Legal, cultural, and Institutional arrangements that determine what publicly traded corporations can do, who controls them, how that control is exercised, and how the risks and returns from the activities they undertake are allocated". According to Shleifer and Vishny (1997) "Corporate governance deals with the ways in which suppliers of finance to corporations assure themselves of getting a return on their investment”. Kensey and Wright (1997), explain that corporate governance is the "entire network of formal and informal relations involving the corporate sector and society in general”. According to Garrett (2000) corporate governance "concerns the appropriate board structures, processes and values to drive the enterprise forward to achieve the organization's purpose whiles keeping it under prudent control". To Cadbury (2003) in its broadest sense, corporate governance is concerned with holding the balance between economic and social goals and between individual and communal goals. The governance framework is there to encourage the efficient use of resources and equally to require accountability for the stewardship of those resources. The aim is to align as nearly as possible the interest of individuals, of corporations, and of society. To OECD (2004) "Corporate governance involves a set of relationship between a company's management, its board, its shareholders and other stakeholders".

Good corporate governance shows why and how a corporation should be managed. Corporate governance is all about a system that demands integrity, openness, straightforwardness, fairness, timely reporting from management of the firm. It also includes compliance with relevant laws guiding the operations of the firm. It also requires adequate disclosures, reporting, truthfulness in structuring derivatives and other financial products. Financial engineering and derivatives are like electricity which can be beneficial and destructive if not properly used. Derivatives can also be related to a two edged sword that must be handled very carefully. The nature of financial engineering and derivatives - their complexity, "two-edged sword" characteristics, demand the need to ensure a sound system of internal controls and governance in firms and Institutions that issue or use financially engineered products. This will help ensure greater internal oversight over the activities of derivatives handlers in such institutions. The misuse/misapplication of financial engineering and its products can be very devastating and therefore, there is need for a good system of corporate governance to guide the use of financial engineering products. Hull (2006) highlighted cases of derivatives mishaps resulting from the wrong application of derivatives instruments. Some of the misapplication resulted from lack of internal controls and sound corporate governance. Instituting sound internal controls and corporate governance practices in the firms that use derivatives and other financially engineered products will help to moderate the risk of mis-use. According to Al-shboul and Alison (2009), corporate governance can provide mechanism to effectively monitor the use of derivatives.

Allayannis et al. (2004) find that the foreign currency hedging premium is statistically significant and economically large only for firms that have strong internal and external corporate governance. Corporate governance can provide mechanism to effectively monitor the use of derivatives (Al-Shboul \& Alison, 2009). Corporate governance is necessary for participants in the financial market to trust the people, place, product, processes, price and promotion offered by the market and its players. Since the derivatives market in itself is considered risky, its modus oparandi must be characterized by transparency and good governance. While some people have blamed the Global Financial Crises (GFC) on derivatives, the real issue with GFC seems to be corporate governance and regulatory problems. The report of the Financial Crises Inquiry Commission (FCIC) released on January $27^{\text {th }} 2011$, identified the causes of the GFC to include: widespread failure in financial regulation; dramatic breakdowns in corporate governance including too many finan- 
cial firms acting recklessly and taking on too much risk; explosive mix of excessive borrowing and risk by households and Wall Street that put the financial system on a collision course with crises; key policy makers ill prepared for the crises, lacking a full understanding of the financial system they oversaw; and system breaches in accountability and ethics at all levels (FCIC, 2011). All these issues in one way or the other relate to corporate governance and regulatory failures.

According to Katz (2011), for market to work, they need market institutions that includes regulations that prevent conflict of interest and fraud and that align the compensation package to top executives with the interest of the firm whose fate is entrusted to their hands. Katz (2011) queried: "But why assume that sound regulations hurt investments? Isn't the opposite more likely? Wouldn't Investors be more likely to entrust their savage to financial markets where a triple. A rating actually means something and where a derivative issued by Wall Street can be trusted?"

He queried further "wouldn't greater investor confidence in the honesty of the market provide firm with more capital at a lower risk adjusted cost? Just as effective commodity regulations have helped grain and meat futures provide us more food at lower cost, so would effective financial regulations boost economic output'. He emphasized the need of sound regulation and corporate governance in order to boost investor confidence in the financial markets. The culture of corporate governance is yet to be fully enshrined across firms in Nigeria. While the SEC has issued a corporate governance code, there is no proper mechanism for monitoring compliance and for sanctioning offenders or even rewarding firms with good corporate governance practices. However the market itself rewards corporate governance as Nigerian investors are willing to pay as much as $50 \%$ premium on shares of companies with good governance (Osuoha, 2011). The implication is that corporate governance can be value additive for Nigeria financial market. Corporate governance can help to deepen the market by attracting more investors at a good value to the firm and the economy.

\section{Responsibility of the Baord, Board Structure and Derivatives Use}

According to Malina and Herman (2007), Plaintiffs are demanding corporate governance reform to resolve derivative litigations. To them the reform should include changes in board composition, right to nominate a board member, the election of non-executive chairman and restriction on board membership. Fama and Jensen (1983) argue that outside directors have greater incentives to make decisions that benefit shareholders than do inside directors. Weibach (1988), Bryrd and Hickman (1992) Borokhovich et al. (1999) report a more favorable reaction by the equity markets to decision made by boards with greater proportion of outside directors. Management, though skilled in running a firm in a particular industry, lacks the broader knowledge supplied by the outside directors. In a study "Board Composition and Corporate use of Interest Rate Derivatives”, Borokhoviah et al. (2004) established a positive relation between the relative influence of outside directors and the quantity of derivatives used, indicating that outside directors take an active role in derivatives usage and that firms employ hedging in the shareholders best interest. The study also shows a significant and positive relation between the quantity of interest rate derivatives used by firms and the proportion of outside directors on the firm's board. The size of the board has also been found not to be significantly related to the quantity of corporate derivatives use (Borokhovich et al., 2004). There is no evidence to suggest that managers benefit from corporate interest rate derivatives use at shareholders expense. But Griffth (2011) argues that independent directors have not demonstrated any special skill to monitor or manage risk. According to Griffth (2011), most board members of AIG were independent apart from 2 of the 12 - 16 board members of the parent company. Enron had 11 independent directors out of the 14 board members. Also Citigroup had majority of its board members as independent and yet they accumulated toxic assets. These independent board members could not discover nor manage the excessive risk taking of their firms. Group of thirty report (1999) focused on the board of directors as a primary source for the oversight of derivatives use. This followed the losses incurred through the use of derivatives by Procter and Gamble, Gibson Greetings and other firms and the far greater oversight of derivatives (Brorokhoviah et al., 2004). Breeden (2004) also reechoes this call for greater oversight over derivative policies adopted by firms. But a firm's risk-management policies, especially those pertaining to the use of derivatives should be strongly influenced by the policies of the Board of Directors (Borokhoviah et al., 2004). Duffie (2009) after reviewing the institutional features of derivatives market outlining what went wrong during the financial crises, recommends that to reduce systematic risk or improve the efficiency of the derivatives markets, there is need for centralized clearing, improved price transparency, improved position transparency, migration of Over the Counter (OTC) derivatives trading to organized exchanges, fixing speculative position limits, and improved corporate governance.

There should be greater board oversight, supervision and monitoring of officers that are responsible for derivatives trading decisions. The board must avoid a "sit down look" or "o yes" disposition when handling issues affecting the company especially issues of derivatives and financial engineering. Both inside and outside directors should be involved as they all have roles to play. Directors of firms that employ the use of derivatives should undergo training on financial engineering and derivatives to equip them properly to supervise the management and officers responsible for derivatives trade. Adoption or introduction of new financially engineered products should first receive the approval of the board that must first ensure that adequate system of internal control and governance has been put in place.

Derivatives Market development (DMD) will depend on general financial market development (FMD). A well developed financial market will give rise to increased financial engineering activities and the increased use of derivatives products. Market Participants Activities (MPA) will also enhance or hurt the development of derivatives market. Good Corporate governance practices (CGP) will also improve the derivatives market as more people will have confidence in the financial market place and will be willing to commit their hard earned resources into it. The regulatory framework (RFM) is also important as it will determine the environment under which the entire market will be operating. See Figure 3.

\section{Regulation of Financial Engineering and Derivatives Markets}

The Global Financial Crises (GFC) has demonstrated that both 


\section{J. I. OSUOHA}

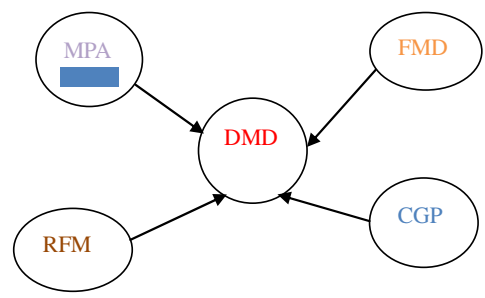

Figure 3.

Derivatives market development drivers. DMD: Derivatives Market Development; FMD: Financial Market Development; CGP: Corporate Governance Practice; RFM: Regulatory Framework; MPA: Market Participants Activities; Source: Author.

global and domestic regulatory structures should be revisited. The GFC shows that regulation is needed to ensure that economic advancement are well being facilitated (Legg \& Harris, 2009). Derivatives and financial innovations generally can offer significant private and social value. The emergence of new financial innovation and financial engineering process involving derivatives can cause even the most sophisticated financial institution to make mistakes. It can also affect the core corporate governance mechanism. For example, equity decoupling, described as the separation of the voting rights associated with equity from the usual economic interest, can affect the core internal and external mechanism of corporate governance such as the shareholders vote and the market for corporate control (Hu, 2011).

An Australian study by Saunders (2010) advocates that Default Swap (an OTC derivative) issuers is subject to prudential regulation in order to improve systemic stability in the financial system. He compares Credit Default Swap to Insurance that must be subject to prudential regulation, just like Insurance Companies. The argument is that since CDS perform the economic function of assuming Credit risk and so should be regulated in the same way as other entities that assume credit risk. Nelson (2010) advocates that if the initiatives taken to increase the competitiveness of OTC derivatives market in Europe are not effective in the near future, a code of conduct could be envisaged. Prudential regulation will reduce systemic instability (Saunders, 2010). Title VII of the Dodd-Frank Wall Street Reform and Consumer Protection Act set forth a wholly new regulatory structure for OTC derivatives. The regulation of OTC derivatives under the Act has three primary goals, namely the minimization of systemic risk from derivatives transaction; the establishment of transparency in derivatives market and the creation of credit protection for derivatives counter parties.

Regulation is essential for an effective operation of a derivatives market. Most OTC products are unregulated while exchange traded derivatives are subject to regulation. Financial regulation in most African states still remains challenging. This has the potentials to threaten the future growth prospects of African financial markets (Salami, 2011). International standards do not take into account the peculiarities of financial systems in Africa and making application of international standards in Africa difficult and challenging (Salami, 2011). Most African legal systems are weak in enforcement of contract of property and insolvency laws. This does not provide the right environment for the smooth operation of African capital markets and regulations (Salami, 2011). The challenging aspects of banking regulations in Africa have been identified by Kew and Patterson (2009); Salami (2011) to include lack of independence of regulators, poor corporate governance, poor enactment of banking regulations and poor accounting standards. These are similar to the same challenges facing the regulation of Derivatives market since the Derivatives market is part of the financial system. Most African countries do not have derivatives market, with the exception of South Africa and the North African economies of Morocco, Egypt and Tunisia where the volume of derivatives transaction is small but growing (MFW4A, 2012). Mauritius, part of eastern Africa has a growing derivatives market. Nigeria has no active derivatives market but OTC derivatives transactions take place, especially among financial institutions. The Abuja Commodity Exchange established in 2006 only trade spot although have long term plans to start trading futures on the commodities they offer (Osuoha, 2010). To make the derivatives market work as expected and to encourage the emergence and growth of the derivatives market there is need for a regulatory framework. Financial regulation can be in direct or indirect forms. Direct financial regulation occurs through the role and powers of government regulators. Indirect regulation can occur through the use of non-government bodies who act as gatekeepers such as credit rating agencies, Auditors, lawyers to mention but a few (Legg \& Harris, 2009).

There is no government body charged with the responsibility of regulating the derivatives market in Nigeria. This may be due to the fact that no organized derivatives market exists in Nigeria at present. However, most traders in OTC derivatives in Nigeria are banks and financial institutions who are already being regulated by the CBN and the SEC. The focus of these regulators is on the primary activities of these firms and not on derivatives. Banks in Nigeria usually engage in foreign exchange forward contracts, swaps which are OTCs. The CBN guidelines for these OTC trades are grossly inadequate as they do not address all aspects of derivatives transactions. A much more robust regulatory framework is needed. However, it may not be feasible to regulate all OTC derivatives trade especially for players who do not fall within already regulated firms. An attempt to over regulate OTC trades may lead to regulatory arbitrage which can be detrimental to the growth and development of the Nigerian economy. Such regulatory attempt can become counterproductive and self-defeating.

\section{Recommendations}

The following recommendations are made in this paper.

1) There is need to introduce an organized derivatives market in Nigeria where financially engineered products can be traded. Futures and options and other derivatives can be structured on Nigeria Oil and gas minerals, to make them easily tradable and easily accessible to foreign investors. This will boast capital flow, increase fluidity with attendant economic benefits.

2) The Nigerian financial market with growing money and capital markets will be incomplete without financial engineering products like derivatives, which are useful in managing the risks associated with the financial system. Absence of financial engineering and derivatives market leaves the Nigeria financial system vulnerable, risky and unattractive to foreign participants, because of lack of hedging mechanism to manage their risk of investing in Nigeria financial market. The stock market, Agricultural/Commodities market, Energy market and other basic 
markets will all experience tremendous increase in patronage with development of the derivatives market in Nigeria. Therefore, the Nigeria policy makers should consider putting in place policies aimed at encouraging the growth of the derivatives market to enhance financial engineering and innovation.

3) Before embarking on establishment of a derivatives exchange in Nigeria, there is need to institute system of corporate governance across listed firms and financial institutions involved in financial engineering. Although the Nigerian SEC has issued a code of corporate governance for public companies in Nigeria, they should ensure compliance. The CBN also has code of corporate governance for Banks in Nigeria. There should be enforceable sanctions for non-compliance to good corporate governance. The regulators should step up in their monitoring of compliance.

4) Futures and options market when established can begin by trading on selected quoted equities, Nigeria Oil resources, FOREX and some selected agricultural produce such as maize, cocoa etc. Over time, product offering by the derivatives market can be expanded to include more derivatives product types and other classes of assets (See Derivatives Type Tree (DTT) in Figure 4).

5) There is also need for a robust regulatory framework to guide the operation of the derivatives exchange in Nigeria. The guideline should provide market structure and mechanism for trading, margining system, trade registration and reporting, clearing and other necessary market infrastructure. Other related regulations and investments laws should be strengthened and modernized to create a good environment for efficient workings of the derivatives market.

\section{Conclusion}

Most financial engineering products in Nigeria are traded OTC with the attendant problems of illiquidity, default risk and lack of standardization. Nigeria government and corporate leaders should fast tract the establishment of derivatives exchange in Nigeria where futures and options on Nigeria Mineral resources, agricultural produce and other basic instruments can be traded. This will aid price discovery, market completeness, leverage benefits, risk management and market efficiency. This will also attract more foreign investments in the Nigeria financial market thus boosting liquidly of the market, creating jobs,

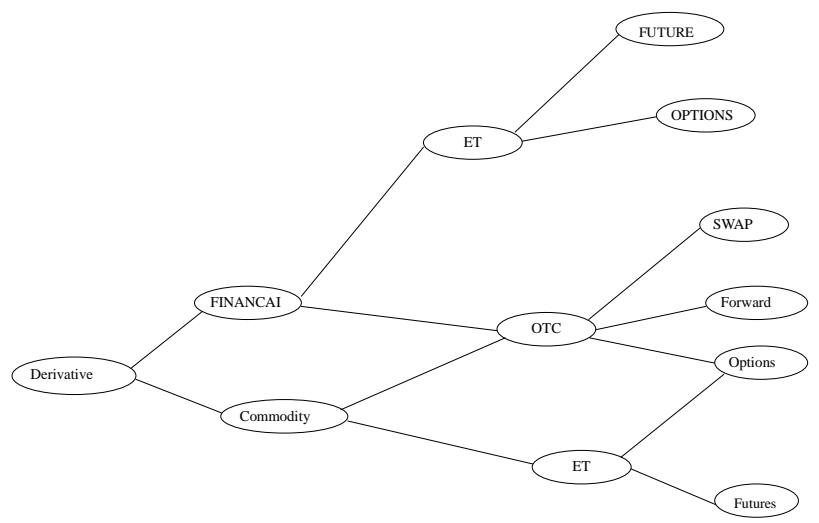

Figure 4.

Derivatives Type Tree (DTT). OTC: Over The Counter; ET: Exchange Traded; Source: Author. increasing market depth and enhancing economic growth.

\section{REFERENCES}

Allayannis, G., \& Ofek, E. (2001). Exchange rate exposure, hedgingand the use of foreign currency derivatives. Journal of International Money and Finance, 20, 273-296.

http://dx.doi.org/10.1016/S0261-5606(00)00050-4

Al-shboul, M., \& Alison, S. (2009). The effects of the use of corporate derivatives on the foreign exchange rate exposure. Journal of Accounting-Business \& Management, Vol. , pp.

Andrianaivo, M., \& Yartey, A. (2012). Understanding the growth of African financial markets. African Development Review, Vol. , pp.

Borokhovich, K. et al. (2004). Board composition and corporate use of interest rate derivatives. The Journal of Financial Research, 27, 199216. http://dx.doi.org/10.1111/j.1475-6803.2004.t01-1-00079.x

Cadbury, A. (1992). Report of the Committee on the Financial Aspects of Corporate Governance. London: Gee \& Co. Ltd.

Chou, Y. K. (2007). Modeling financial innovation and economic growth: Why the financial sector matters to the real economy. The Journal of Economic Education, 1, 78-91. http://dx.doi.org/10.3200/JECE.38.1.78-91

Hu, H. (2011). Financial innovation and corporate governance. NACD Directorship 100 Forum, 50-52.

Hull, J. (2006). Options, futures and other derivatives. Upper Saddle River, NJ: Prentice Hall.

International Swaps and Derivatives Association Inc. (2002). ISDA 2002 Mid-Year Market Survey.

Jensen, M. (1986). Agency costs of free cash flow, corporate finance, and takeovers. The American Economic Review, 76, 323-329.

Lo, A. (2009). Regulatory reform in the like of financial crisis of 20072008, March 10.

Malian, S. M., \& Herman, B. A. (2007). Additional issues for derivatives cases, corporate governance and disclosure. Morgan, Lewis and Bockins LLP.

Osuoha, J. (2010). Commodity trading and futures. Lagos: Emmaesth Printing \& Publishing.

Osuoha, J. (2011). Evaluation of the Nigeria price system and its role in the underdevelopment of the Nigerian economy. Nigeria Economics Students Association Workshop, Akoka: University of Lagos.

Osuoha, J. (2011). The effect of corporate governance on corporate performance: The case of Nigeria quoted firms. M.Sc. Thesis, Leeds: Leeds Metropolitan University.

Salami, I. (2011). African capital market—Going global or not? Journal of International Banking Law and Regulation, Vol. , pp.

Salami, I. (2011). Financial regulation in Africa frontier markets: Can the EU approach work? Law and Financial market Review, 5, 380387.

Saunder, B. (2010). Should credit default swap issuers be subject to palatial regulation? Journal of Corporate Law Studies, 10, 437-450.

Schumpeter, J. (1911). The theory of economic development. Cambridge, MA: Harvard University Press.

Sheleifer, A., \& Vishny, R. W. (1997). A survey of corporate governance. Journal of Finance, 52, 737-783.

Solow, R. M. (1956). A contribution to the theory of economic growth. Quarterly Journal of Economics, 70, 65-94.

Tricker, R. I. (1984). Corporate governance: Practices, procedures and powers \& British companies and their boards of directors. In G. Maaseen (Ed.), An international comparison of corporate governance models (pp. ). The Netherlands: Spencer Stuart. 